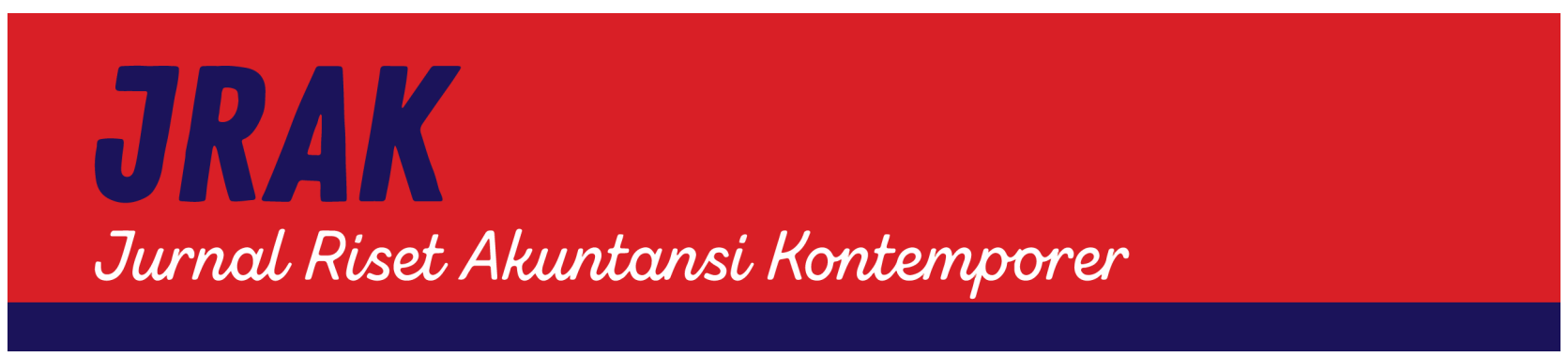

\title{
DETERMINANTS OF COMMERCIAL BANKS PROFITABILITY: EVIDENCE FROM GERMANY
}

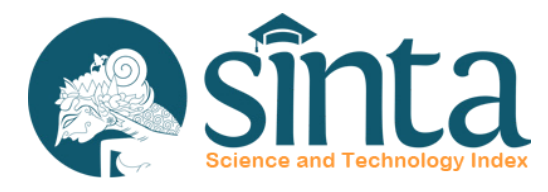

https://journal.unpas.ac.id/index.php/jrak/index

\author{
Szilard Farkasdi ${ }^{1} \bowtie$, Budi Septiawan ${ }^{2}$, Erik Syawal Alghifari ${ }^{3}$ \\ ${ }^{1}$ IDC Financial Insight, ${ }^{2,3}$ Universitas Pasundan \\ $\triangle 1$ szfarkasdi@gmail.com \\ 85 Uxbridge Rd, London W5 5TH, United Kingdom
}

\section{Article Info}

History of Article

Received: 9/9/2021

Revised: 25/9/2021

Published: 18/10/2021

Jurnal Riset Akuntansi Kontemporer

Volume 13, No. 2, October 2021, Page 82-88

ISSN 2088-5091 (Print)

ISSN 2597-6826 (Online)

Keywords: commercial banks; profitability; determinant factors; germany; europe

\begin{abstract}
This study aims to determine the determinants of profitability in commercial banks in Germany. The population is 7 banking sector companies listed in the DAX (Deutscher Aktienindex) Bank during the 2017-2020 period, with a sample of 5 banks and producing 20 observational data. The method used is descriptive and verification with multiple regression analysis. The results show that asset size, capital adequacy, deposits and non-interest income have a significant positive effect on profitability. Partially, asset size, capital adequacy and non-interest income have a significant positive effect, while the deposit has a significant negative effect on profitability. The most dominant factor affecting profitability is non-interest income.
\end{abstract}

\section{INTRODUCTION}

The Covid-19 pandemic has had a huge impact on the global economy, including the banking sector. Problems do not only revolve around the demand and supply of banking products, but also have an impact on the financial system as a whole. Especially in terms of financial transactions and international trade (Obeidat et al. 2021). Banks have become an important industry whose performance will always be in the spotlight, including its development from a financial and non-financial perspective (Helhel, 2014). Furthermore, banks are intermediary institutions that support other industries. Banks are not only responsible for those who save money, but also those who borrow money (Bezawada, 2020).

Based on research conducted by Fernandez-Bollo et al. (2021) it was found that the coronavirus forced many banking sectors in Europe to risk low profitability, this will be a challenge for the banking sector, because banking profitability is one indicator of financial stability in a country or region. The banking sector basically plays an important role in sustaining the economy in Europe (Horobet et al. 2021). During the economic crisis in 2008, several banks in Central and Eastern Europe were quite able to survive, this was due to proper regulation and also high profitability before the crisis occurred.

Profitability is quite crucial as well as complicated during the Covid-19 pandemic, many banks experience losses or financial difficulties. Factors that affect bank profitability can come from external or internal sources (Wahdan and Leithy, 2017). External factors include macroeconomic policies from the government, central bank 
interest rates, climate change and the current pandemic (Serwadda, 2018). Meanwhile, internal factors include interest income, non-performing loans, capital adequacy ratio, size of company assets and others (Islam et al. 2017).

Commercial banks in Europe in general have experienced underperforming since several years before the pandemic. Starting from the global financial crisis in 2008, commercial banks in Europe experienced a significant decline in profitability in mid 2010-2012, they never felt a good cost of equity ratio, plus the high ratio of non-performing loans at that time (Fernandez-Bollo et al. 2021). Based on research conducted by Altavilla et al. (2021), commercial banks in Europe are always under commercial banks in the USA, in terms of return on equity. This can be seen in the following diagram;

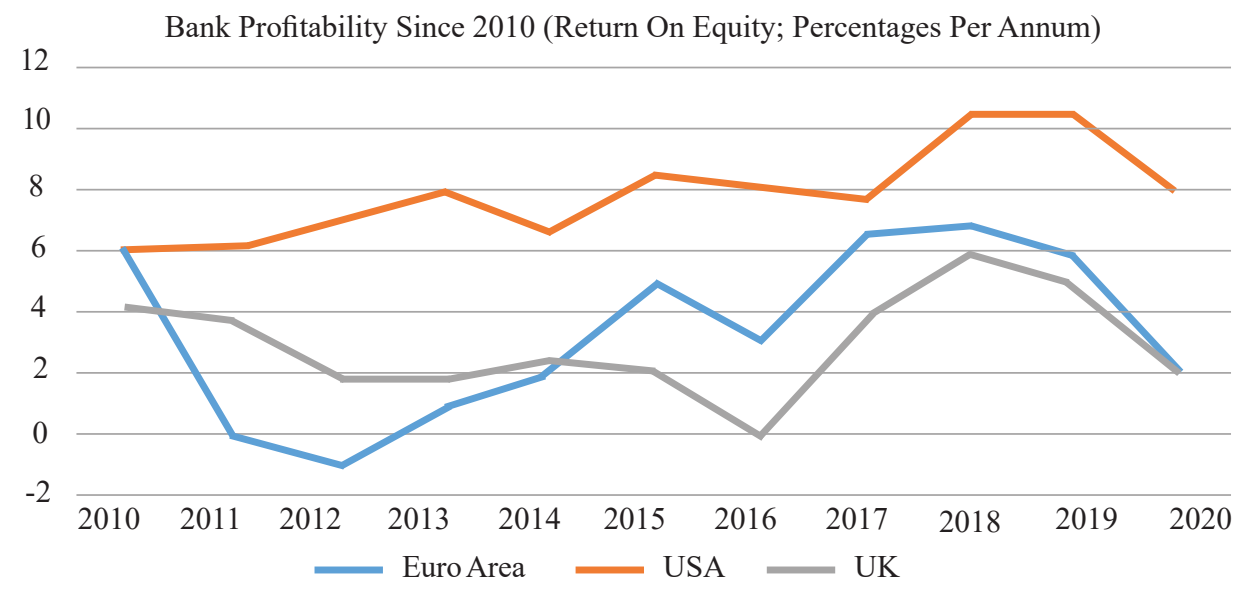

Figure 1. Bank Profitability Comparison among Euro Area, USA and UK

Source: Bloomberg and ECB Calculations (2021)

Speaking of the banking sector in Europe, the banking system in Germany is one of the best. Banks in Germany have a fairly stable banking system, this can be seen from the role of banks in their contribution to low unemployment and economic resilience in Germany (Schuler, 2017). On the one hand, the toughest challenge for the banking industry in Germany is the level of persistence in earning profits, and reducing operational costs or the cost of funding. (Petria et al. 2015). There needs to be a synergy between the monetary economic sector, which is dominated by banks, and the real economic sector, which is supported by the manufacturing industry in Germany, without good non-financial companies, commercial banks in Germany will not be able to earn high profits (Koch, 2015).

Profitability in banking is crucial, because banking is part of the financial system in a country, especially in Europe. The financial system consists of financial intermediaries, markets and market infrastructures, while banks are the largest credit providers in Europe (Fell and Schinasi, 2005). Banks in Germany suffered a significant impact during the period 2019 to 2021, especially during the period of the Covid-19 pandemic, banks in Germany were considered less able to develop during this period. Based on the results of a survey released by S\&P Global Market Intelligence in 2020, German banks were the lowest in terms of return on equity (ROE) until the end of 2019 at $-0.2 \%$. The aggregate net profit of the banking sector in Germany was only $€ 8.24$ billion, a far cry from France's $€ 29.48$ billion, U.K.'s $€ 25.62$ billion, Spain's $€ 17.43$ and even Italy's $€ 11.29$ billion (Damyanova and Garrido, 2020).

Banks in Germany must take appropriate steps to improve this condition, before the condition worsens. Banks in Germany must be able to increase their profitability ratios in the midst of the European economy which is starting to get excited again (Väth, 2021). Internal factors will be the focus of this research, where these internal factors are related to the ability of banking management to manage their business to achieve maximum profit (Javaid et al. 2011). Internal factors such as asset size, income, capital adequacy ratio and deposits will be tested as factors driving the profitability of banking in Germany. This study focuses on internal factors due to economic conditions that are currently experiencing a recession, so that internal factors will be more interesting to study. Thus, commercial banks will be better able to prepare their internal side, in the face of uncertain external conditions, the population in this study is indexed commercial banking in DAX (Deutscher Aktienindex).

This study certainly aims to determine the key factors that will drive the profitability of commercial banks in Germany. This will be an interesting thing to research, because Germany is one of the countries in Europe that has the highest GDP in Europe and even the world, it's just that the impact of the pandemic still hits the 
country's economy, especially the banking sector. This study reveals the factors and policies that can be taken by the banking industry in Germany in increasing profitability. Research on the factors that affect the profitability of banking has been conducted by (Messai et al. 2015), (Duraj and Moci, 2015), (Titko et al. 2015), (Elisa and Guido, 2016), (Alshatti, 2016), (Le and Ngo 2020). These studies reveal the dominant factors that will drive profitability in the banking sector.

\section{METHOD}

The method used is descriptive and verification. Variable operationalization is shown in Table 1. The population is the commercial banking sector companies included in DAX (Deutscher Aktienindex) during the 2017-2020 period as many as 7 banks. The sampling technique is purposive sampling, with company criteria that are included in DAX (Deutscher Aktienindex) and publish financial reports, during the study period. The sample is 5 banks with a total of 20 observations (Table 2). Data collection techniques used are library research, indirect observation and documentation. Descriptive analysis using the average, maximum, and minimum values. The verification analysis uses multiple regression analysis and to test the hypothesis, the $\mathrm{F}$ test and $\mathrm{t}$ test with Microsoft Excel and SPSS are used, preceded by the classical assumption test. The data is obtained from the financial statements of banking sector companies which include the DAX (Deutscher Aktienindex) banks for the 2010-2017 period, by accessing www.finance.yahoo.com dan www.investing.com.

Table 1. Variables of Profitability Analysis and Their Measurement

\begin{tabular}{llll}
\hline & Variable & Measure & Notation \\
\hline Dependent Variable & Profitability & Return on Equity=Net Profit/Total Equity & ROE \\
Independent Variables & Asset Size & Natural Logarithm of Total Assets & LnA \\
& Capital Adequacy & Equity/ Total Assets & CA \\
& Deposit & Deposits/Total Assets & DP \\
& Income & Non-Interest Income =Non- Interest & NII \\
& & Income/Total Assets & \\
\hline
\end{tabular}

Table 2. List of Sample Banking Sector Companies

\begin{tabular}{cc}
\hline Kode Bank & Nama Bak \\
\hline CBKG & Commerzbank AG O.N. \\
DBKGn & Deutsche Bank AG NA O.N. \\
PBBG & Deutsche Pfandbriefbank AG \\
ARLG & Aareal Bank AG \\
PCZ & ProCredit Holding AG \& Co KGaA \\
\hline
\end{tabular}

\section{RESULT}

Profitability conditions in banking sector companies including DAX (Deutscher Aktienindex) banks during the 2017-2020 period fluctuated and tended to decline (Figure 2). Similarly, capital adequacy (Figure 4) and income (Figure 6), while the condition of asset and deposit sizes fluctuated and tended to increase (Figures 3 and 5). All of the graphs are represented the condition of commercial banks in Germany and indicate real condition. The graphs show that commercial bank must aware about theirs profitability condition, and determine what the crucial factors to increase profitability. 
Profitability

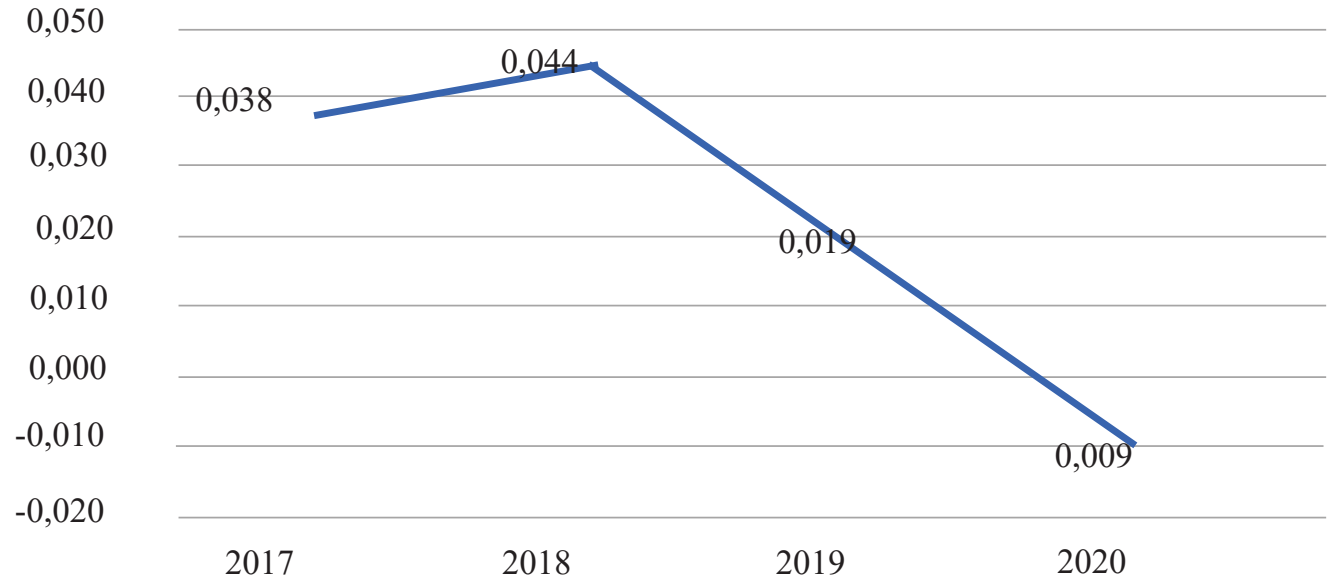

Figure 2. Graph of Average Profitability in Commercial Banking Sector Companies Including DAX (Deutscher Aktienindex) Banks for the 2017-2020 period

\section{Asset Size}

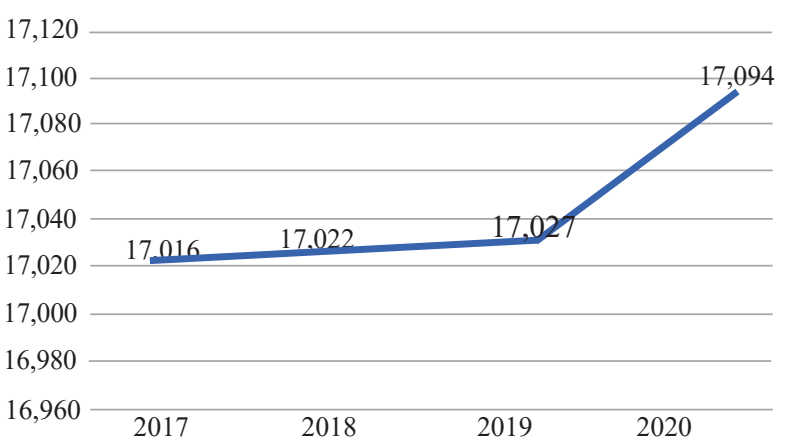

Figure 3. Graph of Average Asset Size in Commercial Banking Sector Companies Including DAX (Deutscher Aktienindex) Banks for the 2017-2020 period

Deposit

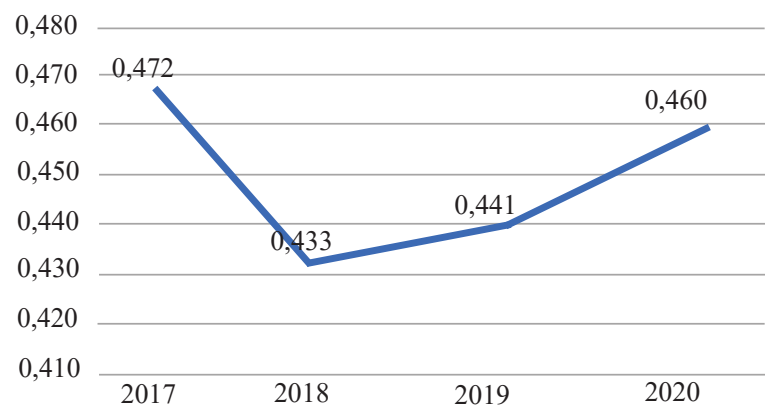

Figure 5. Graph of Average Deposits in Commercial Banking Sector Companies Including DAX (Deutscher Aktienindex) Banks for the 2017-2020 period
Capital Adequency

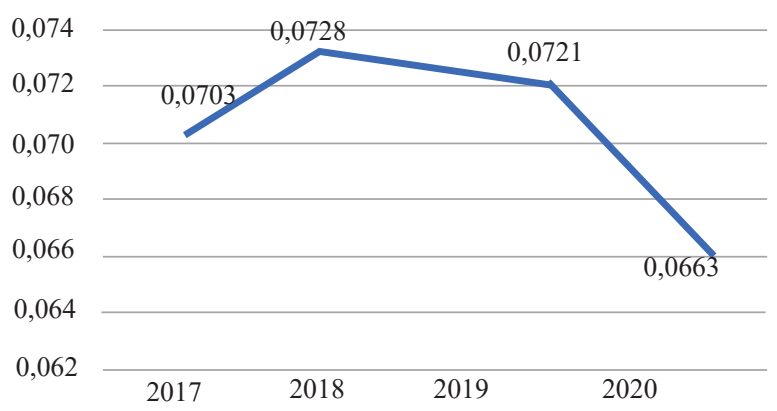

Figure 4. Graph of Average Capital Adequacy of Commercial Banking Sector Companies Included in DAX (Deutscher Aktienindex) Banks for the 2017-2020 period

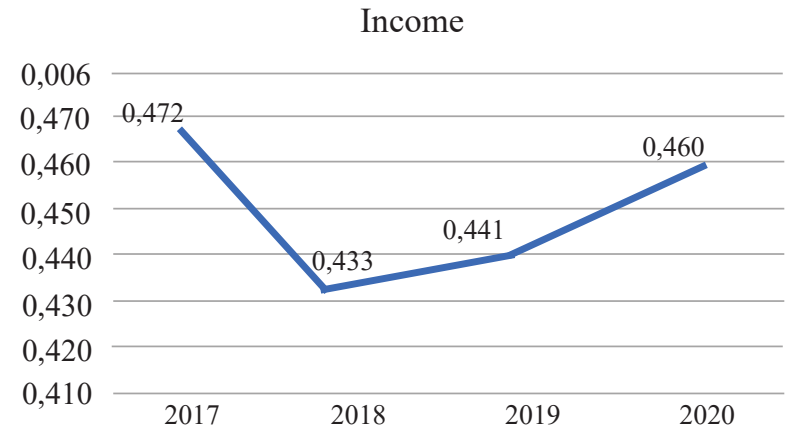

Figure 6. Graph of Average Income in Commercial Banking Sector Companies Including DAX (Deutscher Aktienindex) Banks for the 2017-2020 period 
The results of the classical assumption test show that the data has a normal distribution, there is no multicollinearity, and heteroscedasticity. The results of multiple regression analysis are shown in table 3 to table 5. Asset size, capital adequacy, deposit and non-interest income have an effect of $74.90 \%$ on profitability (Table 2). The coefficient of partial determination consists of (1) the contribution of the influence of asset size of $0.6691 \times-0.1378 \times 100 \%=-0.0922 \rightarrow-9.22 \%$, (2) The contribution of the influence of capital adequacy is $0.5200 \times 0,5124 \times 100 \%=0.2665 \rightarrow 26.65 \%$, (3) The contribution of the influence of the deposit is $-0.6965 \times$ $-0.0775 \times 100 \%=0.0540 \rightarrow 5.40 \%$ (4) The contribution of the influence of non-income interest on profitability is $1.1489 \times 0.4532 \times 100 \%=0.5207 \rightarrow 52.07 \%$ (Table 3 ). Based on hypothesis testing both simultaneously and partially using the F test (Table 4) and t test (Table 3), there is an effect of asset size, capital adequacy, deposits and non-interest income on profitability.

Table 3. Model Summary

\begin{tabular}{|c|c|c|c|c|}
\hline Model & $\mathrm{R}$ & R Square & Adjusted R Square & $\begin{array}{l}\text { Std. Error of the } \\
\text { Estimate }\end{array}$ \\
\hline 1 & $.865 a$ & .749 & .682 & .02889 \\
\hline
\end{tabular}

Table 4. Coefficients ${ }^{\mathrm{a}}$

\begin{tabular}{llllllll}
\hline Model & & $\begin{array}{c}\text { Unstandardized } \\
\text { B }\end{array}$ & $\begin{array}{c}\text { Coefficients } \\
\text { Std. Error }\end{array}$ & $\begin{array}{c}\text { Standardized } \\
\text { Coefficients } \\
\text { Beta }\end{array}$ & $\begin{array}{c}\text { Sig. } \\
\text { Correlations } \\
\text { Zero-order }\end{array}$ & Partial \\
\hline 1 & (Constant) & -.255 & .099 & & .021 & & \\
& LnA & .013 & .005 & .669 & .027 & -.138 & .536 \\
& CA & 1.040 & .360 & .520 & .011 & .512 & .598 \\
& DP & -.154 & .040 & -.697 & .002 & -.078 & -.707 \\
& NII & 14.216 & 3.692 & 1.149 & .002 & .453 & .705 \\
\hline
\end{tabular}

a. Dependent Variable: ROE

Table 5. ANOVA ${ }^{\mathrm{a}}$

\begin{tabular}{ccccccc}
\hline Model & $\begin{array}{c}\text { S u m of } \\
\text { Squares }\end{array}$ & df & Mean Square & F & Sig. & \\
\hline 1 & Regression & .037 & 4 & .009 & 11.190 & $.000 \mathrm{~b}$ \\
& Residual & .013 & 15 & .001 & & \\
& Total & .050 & 19 & & & \\
\hline
\end{tabular}

a. Dependent Variable: ROE

b. Predictors: (Constant), NII, CA, DP, LnA

\section{DISCUSSION}

Asset size is the first key factor that can affect the profitability of banks in Germany. In research, asset size has a significant effect on profitability, the contribution of the influence given is $-9.22 \%$. The year 2019 was a turning point for the increase in the assets of commercial banks in Germany, where in 2020 the banks studied experienced an increase in assets, especially tangible assets owned. This is a positive thing, because of the five German commercial banks that were sampled in this study, asset size fluctuations tended to increase. Asset size is associated with bank size, meaning that the bank has greater resources and is more flexible in innovating or expanding (Athanasoglou et, al 2006). Based on research on commercial banks in Hungary, it was found that banks with large assets tend to have been around for a long time and are more experienced. Large assets will be better if they can be managed well, amid economic uncertainty like today, it would be wise if the banking sector invests more in the IT sector and infrastructure development (Serwadda, 2018), (Le and Ngo 2020).

Capital adequacy also gave positive and significant results in this study, with a contribution of $26.65 \%$. Commercial banks in Germany experienced declining profitability during the 2019-2010 period, so the capital adequacy ratio could be one of the drivers of this bad trend (Tariq et al. 2014). The capital adequacy ratio in the banking sector must be efficient, meaning that there is a balance between assets and liabilities owned. Furthermore, the capital adequacy ratio is related to the proportion of capital to the bank's risk-weighted assets, this will measure the extent to which the capital owned by the bank is able to mitigate risks that may occur 
(Wahdan and Leithy, 2017). Commercial banks in Germany have capital formed from the shares of corporations, meaning that those banks listed on the stock market must be publicly responsible and distribute dividends. Therefore, the management of assets, liabilities and capital optimization needs to be carried out efficiently. In the midst of a pandemic, commercial banks must be able to manage their funding to debtors, lest the NPL ratio increase during this pandemic period (ECB, Deutsche Bundesbank, Federal Financial Supervisory Authority, 2021). Investments in the IT sector to reach a wider range of consumers, and also banks must be able to create artificial intelligence in lending, as has been done by Commerzbank in recent years.

Deposits contributed 5.4\% to the Bank's Profitability in this study. Banks are intermediary institutions between parties who have more funds and those who lack funds. Banks will make every effort to absorb funds from their customers, after the funds come in, banks need to manage them in the right distribution. Banks must be able to convince customers that the funds they manage are safe and of investment value for customers (Haddawee and Flayyih, 2020). However, in this study it was found that large deposits do not have a positive impact on bank profitability. This is because commercial banks in Germany are less able to manage customer funds to be channeled to the right credit during the pandemic. Deutsche Bank AG is one of the commercial banks that continues to strive to prevent customer deposits from being withdrawn, because it is unable to increase interest income, which so far has always been negative (Kowsmann, 2021).

Income has an effect of $52.07 \%$ in this study, meaning that income is the variable that contributes the most to profitability, income used in this study is non-interest income. Non-interest income is income other than interest income, income can be in the form of debit and credit card administration fees, processing loans fees and also income earned by banks from activities in the capital market such as underwriting, advisory, mergers and acquisitions and others (Sanya and Wolfe, 2011). Income from this aspect can be the spearhead during the pandemic, because non-interest income is income that must be earned. Banks can start to focus on non-interest income, rather than interest income that originates from lending, which has a fairly high risk during the pandemic. (Horobet et al. 2021). However, in general, banks in Germany and Europe still rely on interest income as their main income (European Banking Federation, 2020).

\section{CONCLUSIONS}

This study aims to reveal the dominant factors that affect the profitability of commercial banks in Germany. Based on the results of the study, it was found that the size of bank assets, capital adequacy and non-interest income had a positive and significant effect on profitability. While deposits do not have a positive impact on profitability, this happens because commercial banks in Germany are not able to manage customer deposits so that they can be channeled to the right credit. The results of this study indicate that it is time for German commercial banks to start focusing on business lines other than lending. This study also shows that banks must be able to utilize their capital by investing in IT and infrastructure strengthening instruments, with the main goal being innovation and wider consumer reach. Banking regulators in Germany must provide supervision and assistance to banks, and keep the benchmark interest rate at a level that is in line with banking needs.

\section{REFERENCES}

Alshatti, A. S. 2016. Determinants of Banks' Profitability - The Case of Jordan. Investment Management and Financial Innovations 13(1):84-91. doi: 10.21511/imfi.13(1).2016.08.

Altavilla, C., Bochmann, P., Ryck, J.D., Dumitru, A.M., Grodzicki, M., Kick, H., Fernandes, C.M., Mosthaf, J., O'Donnell, C. and Palligkinis, S., 2021. Measuring the cost of equity of euro area banks. ECB Occasional Paper Series No. 254.

Athanasoglou, P., M. Delis, and C. Staikouras. 2006. Determinants of Bank Profitability in the South Eastern European Region. Bank of Greece Working Paper 2(47):1-31.

Bezawada, B. 2020. Corporate Governance Practices and Bank Performance: Evidence from Indian Banks. Indian Journal of Finance and Banking 4(1):33-41. doi: 10.46281/ijfb.v4i1.502.

Damyanova, V., and Francis, G. 2020. Pandemic to Prolong German Banks' Struggle with Low Profitability. S\&P Global Market Intelligence.

Duraj, B., and Elvana, M. 2015. Factors Influencing the Bank Profitability - Empirical Evidence from Albania. Asian Economic and Financial Review 5(3):483-94. doi: 10.18488/journal.aefr/2015.5.3/102.3.483.494.

ECB, Deutsche Bundesbank, Federal Financial Supervisory Authority. 2021. Bank Capital Adequacy Ratio in Germany.

Elisa, M., and Paolucci, G. 2016. Factors Affecting Bank Profitability in Europe: An Empirical Investigation. African Journal of Business Management 10(17):410-20. doi: 10.5897/ajbm2016.8081. 
Federation, European Banking. 2020. Banking Sector Peformance.

Fell, J., and Garry, S. 2005. Assessing Financial Stability: Exploring the Boundaries of Analysis." National Institute Economic Review 192(1):102-17. doi: 10.1177/002795010519200110.

Fernandez-Bollo, É., Desislava, A., Maciej, G., Lise, H., and Rose, P. 2021. Euro Area Bank Profitability: Where Can Consolidation Help?

Haddawee, A. H., and Hakeem, H. F. 2020. Relationship Between Bank Deposits and Profitability of Commercial Banks (Practical Example of Jordan Commercial Bank). International Journal of Innovation, Creativity and Change 13(7). doi: 10.2991/aebmr.k.201215.010.

Helhel, Y. 2014. Evaluating the Performance of Commercial Banks in Georgia. Research Journal of Finance and Accounting 5(22).

Horobet, A., Magdalena, R., Lucian, B., and Sandra, M. D. 2021. Determinants of Bank Profitability in CEE Countries: Evidence from GMM Panel Data Estimates. Journal of Risk and Financial Management 14(7):307. doi: 10.3390/jrfm14070307.

Islam, Md. A., Md. Nazirul, I. S., Mahabub, R., Arifin, S., and AZM Shafiullah, P. 2017. Determinants of Profitability of Commercial Banks in Bangladesh. International Journal of Banking and Financial Law $1(1): 1-11$.

Javaid, S., Jamil, A., Khalid, Z., and Abdul, G. 2011. Determinants of Bank Profitability in Pakistan: Internal Factor Analysis. Journal of Yasar University 23(6):3794-3804. doi: 10.19168/jyu.50211.

Koch, S. 2015. Effects of Shareholder Groups on the Factoring Institutions Profitability: Evidence from Germany. International Journal of Economics and Finance 7(11):39. doi: 10.5539/ijef.v7n11p39.

Kowsmann, P. 2021. Banks in Germany Tell Customers to Take Deposits Elsewhere. The Wall Street Journal.

Le, T.D. and Ngo, T., 2020. The Determinants of Bank Profitability: A Cross-Country Analysis. Central Bank Review 20(2):65-73. doi: 10.1016/j.cbrev.2020.04.001.

Messai, A. S., Mohamed, I. G., and Fathi, J. 2015. Determinants of Bank Profitability in Western European Countries Evidence from System GMM Estimates. International Business Research 8(7):30-42. doi: $10.5539 /$ ibr.v8n7p30.

Obeidat, M., Mohammad, K., Ghassan, O., and Ahmad, T. 2021. The Performance of Banks in a Developing Country: Has Covid-19 Made Any Difference. Pressacademia 8(2):102-8. doi: 10.17261/ pressacademia.2021.1395.

Petria, N., Bogdan, C., and Iulian, I. 2015. Determinants of Banks' Profitability: Evidence from EU 27 Banking Systems. Procedia Economics and Finance 20(15):518-24. doi: 10.1016/s2212-5671(15)00104-5.

Sanya, S. O., and Simon, W. 2011. Can Banks in Emerging Economies Benefit from Revenue Diversification? SSRN Electronic Journal 2025899598(001). doi: 10.2139/ssrn.1077842.

Schuler, C. 2017. Announcement: Moody's Maintains Stable Outlook on Germany's Banking System amid Resilient Operating Environment. Moody's Investor Service.

Serwadda, I. 2018. Determinants of Commercial Banks' Profitability. Evidence from Hungary. Acta Universitatis Agriculturae et Silviculturae Mendelianae Brunensis 66(5):1325-35. doi: 10.11118/ actaun201866051325.

Tariq, W., Muhammad, U., Haseeb, Z. M., Inam, A., and Imran, A. 2014. Determinants of Commercial Banks Profitability: Empirical Evidence from Pakistan. International Journal of Accounting and Financial Reporting 1(1):1. doi: 10.5296/ijafr.v4i2.5939.

Titko, J., Viktorija, S., and Daiva, J. 2015. Drivers of Bank Profitability: Case of Latvia and Lithuania. Intellectual Economics 9(2):120-29. doi: 10.1016/j.intele.2016.02.003.

Väth, H. 2021. German Financial Sector Anticipates Wave of Insolvencies and Accelerated Branch Closures Due to Pandemic Press Release. Center for Financial Studies, 1-2.

Wahdan, M., and Walid, E. L. 2017. Factor Affecting the Profitability of Commercial Banks in Egypt over the Last 5 Year (2011-2015). International Business Management 11(2):342-49. 